\title{
Corynebacterium caspium sp. nov., from a Caspian seal (Phoca caspica)
}

\author{
Matthew D. Collins, ${ }^{1}$ Lesley Hoyles, ${ }^{1}$ Geoffrey Foster $^{2}$ \\ and Enevold Falsen ${ }^{3}$ \\ ${ }^{1}$ School of Food Biosciences, University of Reading, Reading, UK \\ ${ }^{2}$ SAC Veterinary Services, Inverness, UK \\ ${ }^{3}$ Culture Collection, Department of Clinical Bacteriology, University of Göteborg, Göteborg, \\ Sweden
}

\begin{abstract}
A previously unknown Gram-positive, non-spore-forming, non-lipophilic, catalase-positive, irregular rod-shaped bacterium $\left(\mathrm{M} / 106 / 00 / 5^{\top}\right)$ was isolated, in mixed culture, from the penis of a Caspian seal (Phoca caspica). The strain was a facultative anaerobe that was able to grow at 22 and $42^{\circ} \mathrm{C}$. Comparative $16 \mathrm{~S}$ rRNA gene sequencing showed that the organism formed a hitherto unknown subline within the genus Corynebacterium. Sequence divergence values of more than $5 \%$ from other described Corynebacterium species, together with phenotypic differences, showed that the unidentified bacterium represents a previously unrecognized member of this genus. On the basis of phenotypic and phylogenetic considerations, it is proposed that the unknown bacterium isolated from a Caspian seal (strain M/106/00/5 ${ }^{\top}=$ CCUG $44566^{\top}=$ CIP $107965^{\top}$ ) be classified as the type strain of a novel species of the genus Corynebacterium, Corynebacterium caspium sp. nov.
\end{abstract}

The genus Corynebacterium is one of the largest genera within the Actinobacteria and currently embraces over 50 species. Many of the species within the genus have come to light relatively recently due to the application of improved diagnostic methods to facilitate their identification and recognition (Funke et al., 1997). Most of the newly described species have originated from human sources (e.g. Funke et al., 1998; Renaud et al., 2001; Shukla et al., 2001; Sjödén et al., 1998), and the corynebacterial flora of humans is now well established. Much less information is available on the species diversity of corynebacteria associated with animals, although it is clear that much new diversity remains to be discovered from these sources (e.g. Collins et al., 1999, 2001a, b; Fernández-Garayzábal et al., 1997, 1998; Goyache et al., 2003). During the course of a study of bacteria isolated from sea mammals, we have characterized a novel Corynebacterium-like organism from a Caspian seal (Phoca caspica). On the basis of both phenotypic and molecular genetic criteria, we describe a hitherto unknown Corynebacterium species, Corynebacterium caspium sp. nov.

Strain M106/00/5 ${ }^{\mathrm{T}}$ was isolated from the penis of a Caspian seal, in mixed culture with Atopobacter phocae and Streptococcus dysgalactiae (serological group G). The strain

Abbreviation: CAMP, Christie-Atkins-Munch-Petersen.

The GenBank/EMBL/DDBJ accession number for the 16S rRNA gene sequence of C. caspium sp. nov. M/106/00/5 ${ }^{\top}$ is AJ566641. was grown aerobically at $37^{\circ} \mathrm{C}$ on Columbia agar (Oxoid) supplemented with $5 \%$ sheep blood. It was characterized biochemically using the API Coryne and API ZYM systems according to the manufacturer's instructions (bioMérieux). The Christie-Atkins-Munch-Petersen (CAMP) test (with Staphylococcus aureus) was performed as described by von Graevenitz \& Funke (1996). Cell-wall murein was prepared by mechanically disrupting the cells; complete acid hydrolysates were analysed as described by Schleifer \& Kandler (1972). Long-chain cellular fatty acids were analysed using the MIDI microbial identification system. The presence of mycolic acids was investigated by GLC analysis of trimethylsilylated derivatives (TMS-MAME) (Klatte et al., 1994). The 16S rRNA gene of the isolate was amplified by a PCR and directly sequenced using a Taq dye-deoxy terminator cycle-sequencing kit (Applied Biosystems) and an automated DNA sequencer (model 377; Applied Biosystems). The closest known relatives of strain M106/ $00 / 5^{\mathrm{T}}$ were determined by performing database searches in the GenBank/EMBL/DDBJ data libraries. The determined sequence and those of its nearest phylogenetic relatives were aligned using the program CLUSTAL W (Thompson et al., 1994). The resulting multiple sequence alignment was corrected manually and a distance matrix was calculated using the program DNADIST (using the Kimura 2-correction parameter) (Felsenstein, 1989). A phylogenetic tree was constructed using the neighbour-joining method with the program NEIGHBOR (Felsenstein, 1989). The stability of the 
groupings was estimated by bootstrap analysis (350 replications) using the programs SEQBOOT, DNADIST, NEIGHBOR and CONSENSE (Felsenstein, 1989).

The unknown isolate recovered from the penis of a Caspian seal stained Gram-positive, and, upon microscopic examination, appeared as irregular short rods. Cells were non-acid-fast and non-spore-forming. The strain was facultatively anaerobic, non-lipophilic, catalase-positive and oxidase-negative. Using the API Coryne system, positive results were obtained for acid production from glucose and D-ribose, urea hydrolysis and the production of pyrazinamidase. Using the API ZYM test gallery, activity was detected for esterase C-4, ester lipase C8 and trypsin. All other enzyme tests were negative using this kit. An examination of cell-wall murein acid hydrolysates of the strain revealed the presence of meso-diaminopimelic acid as the dibasic amino acid, which is consistent with membership of the genus Corynebacterium. The non-hydroxylated long-chain cellular fatty acids of the organism were found to be primarily of the straight-chain saturated and monounsaturated types. The major acids corresponded to $\mathrm{C}_{14: 0}$ $(2 \cdot 3 \%), \mathrm{C}_{16: 1} \omega 9 c \quad(2 \cdot 6 \%), \mathrm{C}_{16: 0} \quad(48 \cdot 4 \%), \mathrm{C}_{18: 1} \omega 9 c$ $(43 \cdot 4 \%)$ and $\mathrm{C}_{18: 0}(3 \cdot 3 \%)$. TLC analysis of whole-cell methanolysates indicated that mycolic acids were not present in the unknown organism isolated from the seal. This result was confirmed by high-temperature GLC analysis. Despite the absence of mycolic acids, the presence of straight-chain saturated and monounsaturated longchain cellular fatty acids and a cell-wall murein based on meso-diaminopimelic acid, together with morphological and biochemical properties, were strongly indicative that the unidentified bacterium was a member of the genus Corynebacterium. To investigate the taxonomic affinities of the unidentified strain in more detail, a large fragment (1351 bases) of its 16S rRNA gene sequence was determined. Sequence database searches revealed that the strain was most closely related to the Actinobacteria, with species of the genus Corynebacterium exhibiting the highest sequence similarities (data not shown). Treeing analysis confirmed the placement of the seal bacterium within the genus Corynebacterium, with the unknown organism forming a distinct subline with Corynebacterium renale as its nearest relative. Fig. 1 depicts the position of the unknown bacterium within a subset of Corynebacterium species.

Both phenotypic and molecular phylogenetic data show unequivocally that the unidentified bacterium is a member of the genus Corynebacterium sensu stricto. Phylogenetically, the bacterium displays a specific affinity with $C$. renale, a species associated with genitourinary infections in animals, especially cattle (Collins \& Cummins, 1986). The clustering of the seal bacterium with $C$. renale was supported by a bootstrap resampling value of $71 \%$ (Fig. 1). However, a sequence divergence of $5 \cdot 3 \%$ (based on a comparison of 1351 bases) between the unknown organism and C. renale clearly demonstrated that these taxa represent quite

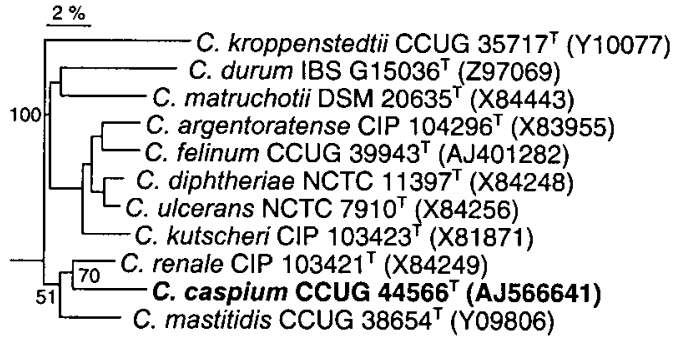

Fig. 1. Neighbour-joining tree, based on a comparison of $\sim 1265$ bases, showing the relationship between C. caspium sp. nov. and some closely related members of the genus Corynebacterium. Bootstrap values (shown at the nodes) are expressed as percentages of 350 replications.

different species. It is now recognized that a $16 \mathrm{~S}$ rRNA gene sequence divergence value of $3 \%$ or more between organisms indicates that they represent different genomic species (Stackebrandt \& Goebel, 1994). Biochemically, the unidentified bacterium closely resembles $C$. renale; however, strains of the latter species can be readily distinguished from the novel seal organism by the production of $\beta$-glucuronidase. The seal bacterium also differs from $C$. renale by producing a negative CAMP reaction and by the absence of mycolic acids. From the treeing analysis, the next nearest relative of the seal bacterium corresponds to Corynebacterium mastitidis, an organism originally isolated from mastitic sheep (Fernández-Garayzábal et al., 1997). The clustering of $C$. mastitidis with the aforementioned pair of species was statistically significant (bootstrap resampling value of $96 \%$ ). However, the unknown bacterium isolated from the seal and C. mastitidis displayed over 5.5\% $16 \mathrm{~S}$ rRNA gene sequence divergence, showing that these taxa are only distantly related. Phenotypically, the seal bacterium can be readily distinguished from $C$. mastitidis in forming acid from a variety of sugars, by its negative alkaline phosphatase reaction and by the absence of mycolic acids. Hence, on the basis of both phenotypic and phylogenetic evidence, we consider that the unidentified bacterium isolated from a seal merits classification as a novel species of the genus Corynebacterium, for which the name Corynebacterium caspium sp. nov. is proposed. Some tests that are useful in distinguishing C. caspium from its nearest relatives are listed in Table 1.

\section{Description of Corynebacterium caspium sp. nov.}

Corynebacterium caspium (cas.pi'um. L. neut. adj. caspium belonging to the Caspian Sea, referring to the isolation of the type strain from a Caspian seal).

Cells are Gram-positive, non-spore-forming, irregularshaped tapered rods and clubs. Colonies were $0.5 \mathrm{~mm}$ in diameter after $24 \mathrm{~h}$, increasing to $2 \mathrm{~mm}$ at $72 \mathrm{~h}$, and were circular, convex, entire, opaque and dull and can be moved 
Table 1. Characteristics that are useful in distinguishing $C$. caspium sp. nov. from its nearest phylogenetic relatives

Species: 1, C. caspium sp. nov.; 2, C. mastitidis; 3, Corynebacterium matruchotii; 4, Corynebacterium durum; 5, C. renale. +, Positive; -, negative; $\mathrm{V}$, variable. Tests are from the API Coryne test system (bioMérieux).

\begin{tabular}{|c|c|c|c|c|c|}
\hline Characteristic & 1 & 2 & 3 & 4 & 5 \\
\hline \multicolumn{6}{|l|}{ Acid from: } \\
\hline Glucose & + & $\mathrm{V}$ & + & + & + \\
\hline Maltose & - & $\mathrm{V}$ & + & + & - \\
\hline Mannitol & - & - & - & + & - \\
\hline Ribose & + & $\mathrm{V}$ & + & + & + \\
\hline Sucrose & - & $\mathrm{V}$ & $\mathrm{V}$ & + & - \\
\hline \multicolumn{6}{|l|}{ Production of: } \\
\hline$\beta$-Glucuronidase & - & - & - & - & + \\
\hline Alkaline phosphatase & - & + & - & - & - \\
\hline Pyrrolidonyl arylamidase & - & $\mathrm{V}$ & + & - & - \\
\hline Urease & + & + & - & $\mathrm{V}$ & + \\
\hline Hydrolysis of aesculin & - & $\mathrm{V}$ & $\mathrm{V}$ & + & - \\
\hline Nitrate reduction & - & - & + & + & $\mathrm{V}$ \\
\hline CAMP reaction & - & - & - & - & + \\
\hline Corynemycolic acids & - & + & + & + & + \\
\hline
\end{tabular}

across the plate whilst retaining their integrity. Facultatively anaerobic, catalase-positive and oxidase-negative. Nonhaemolytic. Non-lipophilic. CAMP-negative. Acid is produced from D-glucose and D-ribose, but not from glycogen, lactose, maltose, mannitol, sucrose or D-xylose. Urea is hydrolysed but aesculin and gelatin are not. Activity is detected for esterase C-4, ester lipase C8, pyrazinamidase and trypsin. No activity is detected for acid phosphatase, alkaline phosphatase, chymotrypsin, cysteine arylamidase, $\alpha$-fucosidase, $\alpha$-galactosidase, $\beta$-galactosidase, $\beta$-glucuronidase, $\alpha$-glucosidase, $\beta$-glucosidase, $N$-acetyl- $\beta$-glucosaminidase, lipase C14, leucine arylamidase, $\alpha$-mannosidase, pyrrolidonyl arylamidase, phosphoamidase or valine arylamidase. Nitrate is not reduced. Cell-wall murein is based on meso-diaminopimelic acid. Corynemycolic acids are not present. The long-chain cellular acids are of the straightchain saturated and monounsaturated types, with $\mathrm{C}_{16: 0}$ and $\mathrm{C}_{18: 1} \omega 9 \mathrm{c}$ predominating; tuberculostearic acid is not present.

The type strain, M/106/00/5 $5^{\mathrm{T}} \quad\left(=\mathrm{CCUG} \quad 44566^{\mathrm{T}}=\mathrm{CIP}\right.$ $\left.107965^{\mathrm{T}}\right)$, was isolated from a Caspian seal. Habitat is not known.

\section{Acknowledgements}

The Scottish Stranding Scheme receives support from the UK Department of Environment, Farming and Rural Affairs (Defra). We are grateful to Thijs Kuiken and Sue Wilson for carrying out the post-mortem of the Caspian seal, and to Hans Trüper, University of Bonn, Germany, for advice on the derivation of the species name.

\section{References}

Collins, M. D. \& Cummins, C. S. (1986). Genus Corynebacterium Lehmann and Neumann 1896, 350 ${ }^{\mathrm{AL}}$. In Bergey's Manual of Systematic Bacteriology, vol. 2, pp. 1266-1276. Edited by P. H. A. Sneath, N. S. Mair, M. E. Sharpe \& J. G. Holt. Baltimore: Williams \& Wilkins.

Collins, M. D., Hoyles, L., Lawson, P. A., Falsen, E., Robson, R. L. \& Foster, G. (1999). Phenotypic and phylogenetic characterization of a new Corynebacterium species from dogs: description of Corynebacterium auriscanis sp. nov. J Clin Microbiol 37, 3443-3447.

Collins, M. D., Hoyles, L., Foster, G., Sjödén, B. \& Falsen, E. (2001a). Corynebacterium capitovis sp. nov., from a sheep. Int J Syst Evol Microbiol 51, 857-860.

Collins, M. D., Hoyles, L., Hutson, R. A., Foster, G. \& Falsen, E. (2001b). Corynebacterium testudinoris sp. nov., from a tortoise, and Corynebacterium felinum sp. nov., from a Scottish wild cat. Int J Syst Evol Microbiol 51, 1349-1352.

Felsenstein, J. (1989). PHYLIP - phylogeny inference package (version 3.2). Cladistics 5, 164-166.

Fernández-Garayzábal, J. F., Collins, M. D., Hutson, R. A., Fernández, E., Monasterio, R., Marco, J. \& Domínguez, L. (1997). Corynebacterium mastitidis sp. nov., isolated from milk of sheep with subclinical mastitis. Int J Syst Bacteriol 47, 1082-1085.

Fernández-Garayzábal, J. F., Collins, M. D., Hutson, R. A., Gonzalez, I., Fernández, E. \& Domínguez, L. (1998). Corynebacterium camporealensis sp. nov., associated with subclinical mastitis in sheep. Int J Syst Bacteriol 48, 463-468.

Funke, G., von Graevenitz, A., Clarridge, J. A., III \& Bernard, K. A. (1997). Clinical microbiology of coryneform bacteria. Clin Microbiol Rev 10, 125-159.

Funke, G., Osorio, C. R., Frei, R., Riegel, P. \& Collins, M. D. (1998). Corynebacterium confusum sp. nov., isolated from human clinical specimens. Int J Syst Bacteriol 48, 1291-1296.

Goyache, J., Vela, A. I., Collins, M. D. \& 7 other authors (2003). Corynebacterium spheniscorum sp. nov., isolated from the cloacae of wild penguins. Int J Syst Evol Microbiol 53, 43-46.

Klatte, S., Kroppenstedt, R. M. \& Rainey, F. A. (1994). Rhodococcus opacus sp. nov., an unusual nutritionally versatile Rhodococcus species. Syst Appl Microbiol 14, 355-360.

Renaud, F. N. R., Aubel, D., Riegel, P., Meugnier, H. \& Bollet, C. (2001). Corynebacterium freneyi sp. nov., $\alpha$-glucosidase-positive strains related to Corynebacterium xerosis. Int J Syst Evol Microbiol 51, 1723-1728.

Schleifer, K. H. \& Kandler, O. (1972). Peptidoglycan types of bacterial cell walls and their taxonomic implications. Bacteriol Rev 36, 407-477.

Shukla, K. S., Vevea, D. N., Frank, D. N., Pace, N. R. \& Reed, K. D. (2001). Isolation and characterization of a black-pigmented Corynebacterium sp. from a woman with spontaneous abortion. J Clin Microbiol 39, 1109-1113.

Sjödén, B., Funke, G., Izquierdo, A., Akervall, E. \& Collins, M. D. (1998). Description of some coryneform bacteria isolated from human clinical specimens as Corynebacterium falsenii sp. nov. Int J Syst Bacteriol 48, 69-74.

Stackebrandt, E. \& Goebel, B. M. (1994). Taxonomic note: a place for DNA-DNA reassociation and 16S rRNA sequence analysis in the present species definition in bacteriology. Int J Syst Bacteriol 44, 846-849.

Thompson, J. D., Higgins, D. G. \& Gibson, T. J. (1994). CLUSTAL W: improving the sensitivity of progressive multiple sequence 
alignment through sequence weighting, position-specific gap penalties and weight matrix choice. Nucleic Acids Res 22, $4673-4680$. von Graevenitz, A. \& Funke, G. (1996). An identification scheme for rapidly and aerobically growing gram-positive rods. Zentbl Bakteriol 284, 246-254. 